\title{
EDUCATION OF COUPLES ABOUT LONG-TERM CONTRACEPTION METHODS IN BATUJAJAR'S HEALTH CENTER THROUGH EDUCATIONAL VIDEOS
}

\author{
Ifa Siti Fasihah 1), Tezza Adriansyah Anwar ${ }^{2)}$, Sri Quintina Indriyana ${ }^{3)}$, Lina Marlinawati ${ }^{4}$ \\ 1) Obstetrics and Gynecology Department, Faculty of Medicine, Universitas Jenderal Achmad Yani, Cimahi, Indonesia \\ 2) Hospital Administration Department, Faculty of Medicine, Universitas Jenderal Achmad Yani, Cimahi, Indonesia \\ 3) Public Health Department, Faculty of Medicine, Universitas Jenderal Achmad Yani, Cimahi, Indonesia \\ 4) Obstetrics and Gynecology Department, Faculty of Medicine, Universitas Jenderal Achmad Yani, Cimahi, Indonesia
}

Corresponding author: tezza_anwar@yahoo.com

\begin{abstract}
This research activity aims to make a video that can be used in digital media to educate couples at the Batujajar Health Center regarding long-term contraceptive methods and evaluate their effectiveness. This research uses a descriptive approach. Questionnaires were also used in this study to see the point of the videos made in increasing respondents' knowledge. A total of 300 people who are still using short-term contraceptive methods have filled out the questionnaire. The educational videos given to respondents were made with an open and comedic concept to make them easier to understand. The evaluation results illustrate that knowledge has increased after watching the videos. The increase is related to the types of methods available and the inaccurate myths. They have not used it mainly because of the perceived high cost of insertion. But they also expressed their willingness to use it, especially for intrauterine devices. Involving a third party who is believed to rectify the incorrect myth, for example, ustadz or ustadzah, who can provide a study of the matter from a religious perspective. An increase in understanding of the cost of installation needs to be made. Information related to this can be conveyed when optimizing the roles of health workers and field instructors. CSR activities or community service from educational institutions in collaboration with the local government and the National Family Planning Coordination Board to eliminate installation costs can be carried out to increase their use.
\end{abstract}

Keywords: Long-Term Contraceptive Methods, Educational videos, Knowledge

\section{Introduction}

One of the targets of Population and Family Planning Development in the 2015-2019 National MediumTerm Development Plan is to increase the number of active family planning participants using the LongTerm Contraceptive Method. The indicator target for this is $23.5 \%$. Meanwhile, the Program Performance and Accountability Survey results showed achievement of 24.6 percent in 2019. So the target has been achieved.

There are 343,869 couples of childbearing age in West Bandung Regency in 2021. While only 274,261 people, or $79.9 \%$, have become active participants in family planning. This means that up to 69,248 people (20.01 percent) have not become active participants in family planning. The short-term contraception method was used by 78.9 percent of the participants, and injection contraception was the most widely used (58.2 percent).

On the one hand, the conditions mentioned above are suitable where modern contraceptive methods have reached 79.9 percent. However, on the other hand, there is still 20.01 percent of people who have not become family planning participants. The next problem is the everyday use of long-term contraceptive methods. Long-term contraceptive methods have proven to be the most effective in reducing pregnancy rates. However, until now, long-term contraceptive methods are still not the choice of most couples of childbearing age in Indonesia (Octaviyani, 2017).

West Bandung Regency itself consists of 16 districts and one of the sub-districts in the Batujajar District. The population of the Batujajar District itself was 97,968 people in 2017. One such facility is the Batujajar Health Center, which provides health services in the Batujajar District.

As stated above, knowledge about short-term and long-term contraceptive methods seems to be easily obtained by the public because of the government's continuous communication, information, and education, especially the BKKBN, which has done so through mass media outdoor media contact with health workers. Or who understands family planning. However, it seems that what has been done has not been effective. It is proven by the percentage of PUS that uses MKJP, which is still low. This is possible because the information conveyed is packaged in general because it must reach all levels of society (using Indonesian and so on). Therefore, we need a particular educational video to be delivered to specific segments of society. Educational videos that will later be distributed through social media are considered the right strategy because almost all people access social media (Instagram, Tiktok, Facebook, etc.).

The purpose of this research activity is to make a video that can be used in digital media to educate couples of childbearing age at the Batujajar Health Center regarding long-term contraceptive methods and 
evaluate the effectiveness of the videos made regarding long-term contraceptive methods. It is essential to conduct this research to increase couples' knowledge regarding long-term contraceptive methods, especially in the Batujajar Health Center area, generally in West Bandung Regency.

\section{Research Methods}

This research uses a descriptive method. Qualitative description (QD) is a label used in qualitative research for descriptive studies, particularly for examining health care and nursing-related phenomena (Polit \& Beck, 2009, 2014 in Stone III., 2004). By using this research method, the two research objectives can be answered.

Questionnaires were also used in this study to see the effectiveness of the videos made in increasing respondents' knowledge about long-term contraceptive methods. Respondents for this questionnaire are couples of childbearing age who are still using short-term contraceptive methods. A total of 300 people have filled out the questionnaire.

\section{Result and Discussion \\ Respondent Profile}

The profiles of respondents in this study are as follows:

Table 1. Profile

\begin{tabular}{|c|c|c|c|c|c|c|c|c|}
\hline Indicator & \multicolumn{8}{|c|}{ Description } \\
\hline Age & $<25$ years & $24,33 \%$ & 25-35 years & $50,00 \%$ & $36-50$ years & $25,67 \%$ & $>50$ years & $0,00 \%$ \\
\hline Education & Junior High & $10,00 \%$ & Senior High & $60,33 \%$ & Diploma & $29,67 \%$ & Bachelor & $0,00 \%$ \\
\hline $\begin{array}{l}\text { Monthly } \\
\text { Expenses }\end{array}$ & $\begin{array}{r}<\mathrm{Rp} .3 \\
\text { millions }\end{array}$ & $61,33 \%$ & $\begin{array}{r}3 \mathrm{~s} / \mathrm{d} 5 \\
\text { millions }\end{array}$ & $38,67 \%$ & $\begin{array}{l}5 \mathrm{~s} / \mathrm{d} 10 \\
\text { millions }\end{array}$ & $0,00 \%$ & $\begin{array}{r}>10 \\
\text { millions }\end{array}$ & $0,00 \%$ \\
\hline $\begin{array}{l}\text { Short-Term } \\
\text { Contraception } \\
\text { User }\end{array}$ & Yes & $100,00 \%$ & No & $0,00 \%$ & & & & \\
\hline $\begin{array}{l}\text { Contraception } \\
\text { method }\end{array}$ & Condom & $0,00 \%$ & Inject & $39,67 \%$ & Pill & $60,33 \%$ & & \\
\hline $\begin{array}{l}\text { Duration of } \\
\text { using } \\
\text { contraception }\end{array}$ & $<2$ years & $24,33 \%$ & 2 s/d 5 years & $49,33 \%$ & $>5$ years & $26,33 \%$ & & \\
\hline Reason of use & Cheap & $51,33 \%$ & Easy to use & $48,67 \%$ & $\begin{array}{r}\text { No side } \\
\text { effect }\end{array}$ & $0,00 \%$ & 0 & $0,00 \%$ \\
\hline Side effects & Yes & $40,67 \%$ & No & 0,59333 & & & & \\
\hline
\end{tabular}

Source: Processed data (2021)

All couples of childbearing age who were respondents in this study were female, dominated by 25-35 years. As for their last education, high school and junior high school graduates dominate the respondents in this study. Respondents are also dominated by monthly expenses of 3 million rupiahs per month.

All respondents are also short-term contraceptive users, dominated by pills and injections that they have used for more than two years. The reason they use short-term contraception is that it is cheap and practical. In addition, most of them have never felt the side effects of using these short-term contraceptives. However, some others have experienced side effects from short-term contraceptives.

\section{Long-Term Contraceptives Methods Educational Video}

The following table shows respondents' responses regarding the educational video provided:

Table 2. Respondents' Responses to Educational Videos

\begin{tabular}{|c|c|c|c|c|c|c|c|c|c|}
\hline \multirow{2}{*}{$\begin{array}{c}\text { Indicator } \\
\text { Attractiveness }\end{array}$} & \multicolumn{9}{|c|}{ Description } \\
\hline & $\begin{array}{r}\text { Very } \\
\text { Unattractive }\end{array}$ & $0,0 \%$ & $\begin{array}{r}\text { Not } \\
\text { attractive }\end{array}$ & $0,0 \%$ & $\begin{array}{r}\text { Less } \\
\text { attractive }\end{array}$ & $\begin{array}{l}\text { Attract } \\
\text { ive }\end{array}$ & $60,7 \%$ & $\begin{array}{r}\text { Very } \\
\text { attractive }\end{array}$ & $38,7 \%$ \\
\hline $\begin{array}{l}\text { Information } \\
\text { clarity }\end{array}$ & $\begin{array}{r}\text { Very } \\
\text { unclear }\end{array}$ & $0,0 \%$ & Not clear & $0,0 \%$ & $\begin{array}{r}\text { Less } \\
\text { clear }\end{array}$ & Clear & $85,0 \%$ & $\begin{array}{l}\text { Very } \\
\text { clear }\end{array}$ & $13,0 \%$ \\
\hline $\begin{array}{l}\text { Clarity of } \\
\text { information } \\
\text { related to } \\
\text { inaccurate } \\
\text { myths }\end{array}$ & $\begin{array}{r}\text { Very } \\
\text { unclear }\end{array}$ & $0,0 \%$ & Not clear & $0,0 \%$ & $\begin{array}{l}\text { Less } \\
\text { clear }\end{array}$ & Clear & $81,0 \%$ & $\begin{array}{l}\text { Very } \\
\text { clear }\end{array}$ & $16,0 \%$ \\
\hline
\end{tabular}




\begin{tabular}{|c|c|c|c|c|c|c|c|c|c|}
\hline \multirow{2}{*}{\begin{tabular}{l}
\multicolumn{1}{c}{ Indicator } \\
Desire to seek \\
more \\
information
\end{tabular}} & \multicolumn{9}{|c|}{ Description } \\
\hline & Don't want & $0,0 \%$ & $\begin{array}{r}\text { Do not } \\
\text { want }\end{array}$ & $0,0 \%$ & less want & $\begin{array}{l}\text { Want } \\
\text { to }\end{array}$ & $46,3 \%$ & Want to & $16,0 \%$ \\
\hline $\begin{array}{l}\text { Willingness to } \\
\text { use long-term } \\
\text { contraceptive } \\
\text { methods }\end{array}$ & Willing to & $87,3 \%$ & $\begin{array}{r}\text { Not } \\
\text { willing to }\end{array}$ & $12,67 \%$ & & & & & \\
\hline $\begin{array}{l}\text { Types of long- } \\
\text { term } \\
\text { contraceptive } \\
\text { methods you } \\
\text { are willing to } \\
\text { use }\end{array}$ & Vasectomy & $0,0 \%$ & Tubectomy & $0,7 \%$ & Implant & IUD & $97,3 \%$ & & \\
\hline $\begin{array}{l}\text { Reasons for } \\
\text { not using a } \\
\text { long-term } \\
\text { contraceptive } \\
\text { method }\end{array}$ & Expensive & $86,7 \%$ & $\begin{array}{r}\text { Not } \\
\text { practical }\end{array}$ & $2,7 \%$ & $\begin{array}{r}\text { Side } \\
\text { effects }\end{array}$ & Other & $6,0 \%$ & & \\
\hline $\begin{array}{l}\text { Willingness to } \\
\text { use if fees are } \\
\text { free }\end{array}$ & Willing to & $96,3 \%$ & $\begin{array}{r}\text { Not } \\
\text { willing to }\end{array}$ & $3,7 \%$ & & & & & \\
\hline
\end{tabular}

Source: Processed data (2021)

The next question was related to the attractiveness of the long-term contraceptive method education video that had been made. Most of the respondents stated that the educational videos were exciting and very interesting. This is because educational videos are made with an open concept and a comedy format, so they are considered more attractive.

Besides being attractive, the educational videos that have been made also provide obvious information related to the types of long-term contraceptive methods. This makes the knowledge of the respondents more understandable and aware of this.

The clarity of information related to the types of long-term contraceptive methods is also supported by the clarity of information associated with the inaccurate myths circulating in the community. This makes them understand that these myths are not valid.

The exciting and precise information about the types of long-term contraceptive methods and the myths circulating in the community make them want to seek more information about long-term contraceptive methods.

Increased understanding from watching educational videos makes most of them willing to use long-term contraceptive methods.

When further asked regarding their willingness to use long-term contraceptive methods, the next question is what type of long-term contraceptive method they are willing to use. Related to this, the intrauterine device (IUD) is a type of long-term contraceptive method that they are eager to use. This is because the IUD has been widely used by colleagues, family, and people known to the respondent.

The next question relates to why they have not used long-term contraceptive methods until now. The main reason for not using a long-term contraceptive method is the perception that the price is considered high. The information they get from friends, family, or people they know. And they have never asked or sought information about this from related parties.

Because the main reason for not using a long-term contraceptive method is that it is expensive, the next question asked is their willingness to use a long-term contraceptive method if the installation fee is free. Most respondents stated that they are willing to use long-term contraceptive methods if the installation fee is free.

\section{Discussion}

After watching the educational video, the knowledge about long-term contraceptive methods among couples of childbearing age in the Batujajar Health Center area. The increase in knowledge is related to the types of long-term contraceptive methods available and the inaccurate myths they have often heard from the people around them. They have not used a long-term contraceptive method to date because of the perceived high cost of insertion. And they also expressed their willingness to use long-term contraceptive methods, especially the IUD type, especially if the installation fee was free.

The inhibiting factors that prevent respondents from using long-term contraceptive methods are:

1. There are still myths circulating in the community related to installations distributed in the community.

2. Respondents' understanding of the cost of installing long-term contraceptive methods is still low, which is considered more expensive than long-term contraceptive methods. 
3. The main reason respondents have not installed a long-term contraceptive method is that the installation cost is relatively more expensive when compared to long-term contraceptive methods. This is what hinders their desire to use long-term contraceptive methods.

\section{Conclusion}

The educational videos given to respondents were made with an open and comedic concept to make them easier for the target community, namely couples of childbearing age in the Batujajar District. The educational video is made into two versions: the long-term contraceptive method for women and the long-term strategy for men. Each of these videos can be accessed on the Youtube account of the Faculty of Medicine, Unjani.

The evaluation results from the educational videos about long-term contraceptive methods illustrate that knowledge about long-term contraceptive methods among couples of childbearing age in the Batujajar Health Center area has increased after watching the educational video. The increase in knowledge is related to the types of long-term contraceptive methods available and the inaccurate myths they have often heard from the people around them. They have not used a long-term contraceptive method to date because of the perceived high cost of insertion. And they also expressed their willingness to use long-term contraceptive methods, especially intrauterine devices, especially if the installation fee is free.

Correcting information on the myths circulating in the community related to the installation of long-term contraceptive methods can be done by involving a third party who is believed to be able to rectify the incorrect myth. For example, the myth that religion (especially Islam) is not justified by inserting foreign objects into the body can include an ustadz or ustadzah, who can study the matter from a religious perspective.

An increase in understanding about the cost of installing long-term contraceptive methods, which are relatively cheaper and more effective than short-term contraceptive methods, needs to be made to understand that long-term contraceptive methods' installation costs are more expensive. Information related to this can be conveyed when optimizing the roles of health workers (in this case, village midwives and independent practice midwives) and health workers at the Puskesmas and field instructors.

Corporate Social Responsibility activities from companies in West Bandung Regency or community service from educational institutions in the health sector in collaboration with the local government and the National Family Planning Coordination Board (BKKBN) to eliminate installation costs can be carried out to increase their use in the community in Batujajar District, West Bandung Regency.

\section{References}

Octaviyani, Putri Rosmalia. 2017. KB Jangka Panjang Minim, https://mediaindonesia.com/humaniora/136893/kb-jangka-panjang-minim, diakses tanggal 23 Februari 2021.

Stone III., J. R. (2004). Math Course Taking for CTE Concentrators: Evidence from Three Studies of the Impact of a Decade of Education Reform. Journal of Career and Technical Education, 21(1), 51-70. https://doi.org/10.1002/nur.21768.Characteristics 